\title{
Bronchial Mucoepidermoid Carcinoma Successfully Treated with Radiation Therapy: A Case Report
}

Kenichi Nishie ${ }^{1}$, Masanori Yasuo ${ }^{1 *}$, Hidekazu Takahashi', Yoko Ozawa ${ }^{1}$, Kazunari Tateishi' ${ }^{1}$, Hiroshi Yamamoto ${ }^{1}$, Keiichiro Koiwai², Takeshi Uehara $^{3}$, Gen Ideura ${ }^{4}$ and Masayuki Hanaoka ${ }^{1}$

${ }^{1}$ The First Department of Internal Medicine, Shinshu University School of Medicine, Matsumoto, Nagano, Japan

${ }^{2}$ Department of Radiology, Shinshu University School of Medicine, Matsumoto, Nagano, Japan

${ }^{3}$ Department of Laboratory Medicine, Shinshu University Hospital, Matsumoto, Nagano, Japan

${ }^{4}$ Department of Respiratory Medicine, National Hospital Organization Shinshu Ueda Medical Center, Ueda, Nagano, Japan

\begin{abstract}
A 69-year-old female presented with dyspnea and dysphagia. Chest computed tomography showed a middle mediastinum tumor compressing the trachea. Biopsy showed mucoepidermoid carcinoma (MEC). A tracheal stent was placed to keep the airway patency and radiation therapy (RT) was started. However, the patient's respiratory status worsened and she was intubated. The intratracheal tumor was reduced using argon plasma coagulation. After restarting RT of $49 \mathrm{~Gy}$, the tumor shrank, allowing the patient to be weaned from ventilatory support. Although MEC is considered RT-resistant, it was beneficial in our case, suggesting that RT is a treatment option for unresectable bronchial MEC.
\end{abstract}

Keywords: Bronchial mucoepidermoid carcinoma; Mucoepidermoid carcinoma; Radiation therapy; Lung cancer; Bronchial stenosis

\section{Introduction}

Mucoepidermoid carcinoma (MEC) of the lung is an extremely rare tumor that accounts for $0.1 \%$ to $0.2 \%$ of all primary lung tumors. Pulmonary MEC was first described by Smetana in 1952 and is pathologically characterized by a combination of mucus-secreting, squamous, and intermediate cell types [1-4]. Mucoepidermoid carcinoma (MEC) originates in the nasal cavity, paranasal sinus, thyroid, bronchus, breast, skin, lacrimal gland, and lacrimal sac [5]. MEC is most commonly seen in salivary glands, accounting for $25 \%$ of malignant salivary tumors [6]. Although both major and minor salivary glands are affected, an intraosseous variant is reported to originate from primitive glandular cells, which are occasionally seen in dentigerous and sialodentigerous cysts, MEC originating in the lungs occurs commonly in the central airways and is known as bronchial MEC [4]. The pathological findings of bronchial MEC, which arises from bronchial glands, are similar to that of MEC from salivary glands.

MEC can be classified into High-grade and low-grade. Highgrade tumors often show irregularly distributed solid and glandular components, with necrosis, whereas low-grade tumors are composed primarily of solid sheets with mucous-secreting cells surrounding pools of mucous [7]. The symptoms of bronchial MEC are cough, dyspnea, wheezing, and obstructive pneumonia related to obstruction of tracheobronchial tree [8]. Sometimes bronchial intervention is needed for airway obstruction due to bronchial MEC [9].

Although no controlled trials that have evaluated treatments for MEC of the lung, surgery is considered the first treatment choice for resectable tumors. Radiation therapy (RT) is regarded as ineffective [10-12].

Here, we present a case of airway obstruction due to a bronchial MEC that was successfully treated with RT.

\section{Case Report}

A 64-year-old female visited the hospital complaining of dyspnea and dysphagia for 2 weeks. She had a 0.5 pack-years smoking history. The physical examination disclosed rhonchi in the anterior chest wall. The laboratory findings showed her white blood cell count as $12,420 /$ $\mathrm{mm}^{3}$, hemoglobin $9.2 \mathrm{~g} / \mathrm{dl}$, and C-reactive protein $5.85 \mathrm{mg} / \mathrm{dl}$. Squamous cell carcinoma antigen (SCC), carcinoembryonic antigen, cytokeratin fragment 19 (CYFRA), and pro-gastrin-releasing peptide levels (ProGRP) were normal and her soluble interleukin-2 receptor level was $629 \mathrm{U} / \mathrm{ml}$ (145 519 U/ml). Chest computed tomography (CT) showed the mass $(4.8 \mathrm{~cm} \times 4.2 \mathrm{~cm} \times 4.8 \mathrm{~cm})$ in the middle mediastinum where it compressed the trachea and esophagus (Figures 1A-1D). She was referred to our hospital for treatment.

Her trachea was so narrow that the bronchoscope $\left(1 \mathrm{~T} 260^{\circ}\right.$,
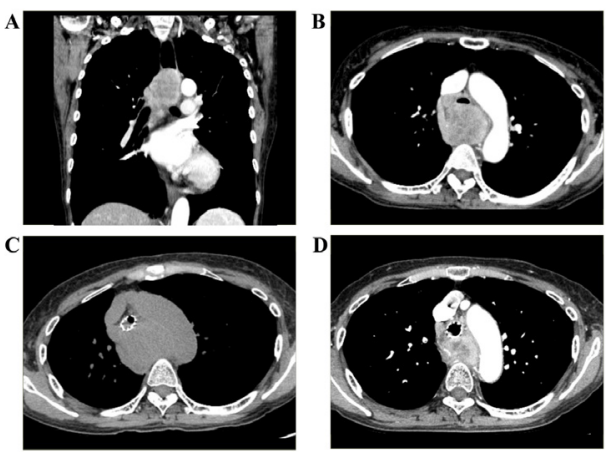

Figure 1: Computed tomography (CT) imaging. A, B: Enhanced chest CT. A bronchial mucoepidermoid carcinoma $(4.8 \mathrm{~cm} \times 4.2 \mathrm{~cm} \times 4.8 \mathrm{~cm})$ was located in the middle mediastinum. C: Tracheal stenosis worsened on day 20 after admission. Chest CT shows that the stent was squashed and the trachea was deviated. D: The tumor shrank $(3.8 \mathrm{~cm})$ and the position of trachea normalized after radiation therapy of 49 Gy was administered.

*Corresponding author: Masanori Yasuo, The First Department of Internal Medicine, Shinshu University School of Medicine, 3-1-1 Asahi Matsumoto, 390-8621, Japan, Tel: ++81-263-37-2631; E-mail: kennishie@imh.jp; yasumasa@shinshu-u.ac.jp

Received: May 30, 2017; Accepted: June 30, 2017; Published: July 03, 2017

Citation: Nishie K, Yasuo M, Takahashi H, Ozawa Y, Tateishi K, et al. (2017) Bronchial Mucoepidermoid Carcinoma Successfully Treated with Radiation Therapy: A Case Report. Oncol Cancer Case Rep 3: 130.

Copyright: $\odot 2017$ Nishie K, et al. This is an open-access article distributed under the terms of the Creative Commons Attribution License, which permits unrestricted use, distribution, and reproduction in any medium, provided the original author and source are credited. 
Citation: Nishie K, Yasuo M, Takahashi H, Ozawa Y, Tateishi K, et al. (2017) Bronchial Mucoepidermoid Carcinoma Successfully Treated with Radiation Therapy: A Case Report. Oncol Cancer Case Rep 3: 130.

Page 2 of 4

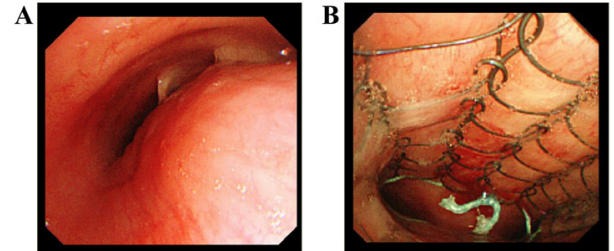

Figure 2: Bronchoscopic findings. A: The trachea was compressed from the posterior wall. B: A stent (Uncovered Ultraflex®, diameter $14 \mathrm{~mm}$, length $30 \mathrm{~mm}$ ) was placed but became pushed and squashed.
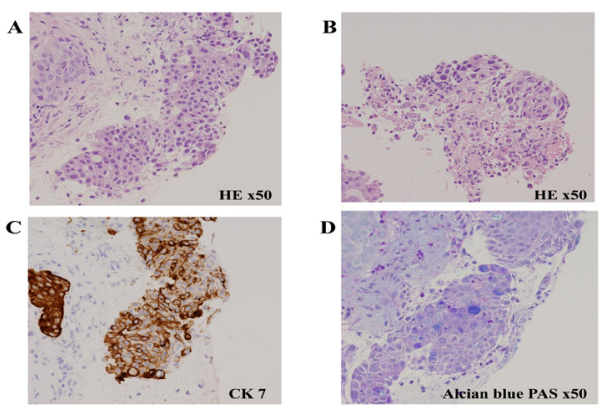

Figure 3: Pathological findings. MEC with predominant epithelial cells and scattered mucin-producing cells with necrosis. CK7 was positive.
Olympus) barely passed through (Figure 2A). To maintain airway patency, we selected and placed an uncovered self-expandable metallic stent (Ultraflex; Boston Scientific, Tokyo; diameter $14 \mathrm{~mm}$, length $30 \mathrm{~mm}$ ) because the tracheal obstruction was severe and there was non-invasive compression from outside (Figure 2B). The surface of a lower portion of the trachea was irregular, exfoliative cytodiagnosis revealed class IIIb, which indicated a borderline of carcinoma. In esophagogastroduodenoscopy, the middle portion of the esophagus was narrow and the surface was clear. Tissue obtained by endoscopic fine-needle aspiration consisted of a mixture of mucusproducing, squamous, and intermediate cells and was positive for Alcian blue Periodic acid-Schiff stain (Figures 3A-3D). Because the immunohistochemical staining was positive for cytokeratin 7 (CK7) (Figure 3C) and negative for Napsin A and thyroid transcription factor 1 (TTF-1), MEC was diagnosed. Anaplasia and necrosis were observed indicating high-grade MEC (Figure 3B) [2,13]. The biopsy was negative for epidermal growth factor receptor mutations, echinoderm microtubule-associated protein-like 4 , and anaplastic lymphoma kinase (EMA4-ALK). Systemic screening with fluorodeoxyglucose positron emission tomography showed metastasis in the right supraclavicular lymph node and right $S 6$.

Palliative RT of 30 Gy given in 10 fractions was planned and started at 16 days after admission. However, airway stenosis became severe during the course of treatment. Chest CT showed that the

\begin{tabular}{|c|c|c|c|c|c|c|c|c|c|}
\hline References & $\mathbf{n}$ & Age & Grade & Treatment & DFS or PFS & $\begin{array}{l}1 \text { year- } \\
\text { survival }\end{array}$ & $\begin{array}{l}3 \text { year- } \\
\text { survival }\end{array}$ & $\begin{array}{l}5 \text { year- } \\
\text { survival }\end{array}$ & other \\
\hline Hsieh 2017 [17] & 41 & $\begin{array}{l}61.4 \text { years } \\
\text { (range, 18- } \\
87 \text { ) }\end{array}$ & $\begin{array}{l}\text { High grade: } \\
n=31 \text { Low } \\
\text { grade: } n=10\end{array}$ & Surgery: $n=41$ & $\begin{array}{c}\text { 5-year DFS } \\
\text { High grade: } \\
54.9 \% \\
\text { Low grade: } \\
66.7 \%\end{array}$ & & & $\begin{array}{l}\text { High grade: } \\
53.2 \% \\
\text { Low grade: } \\
66.7 \%\end{array}$ & \\
\hline \multirow{2}{*}{ Hou 2017 [18] } & \multirow{2}{*}{29} & \multirow{2}{*}{$\begin{array}{c}45 \text { years } \\
\text { (range, 10- } \\
79)\end{array}$} & $\begin{array}{c}\text { High grade: } \\
n=17 \\
\text { Low grade: } \\
n=12\end{array}$ & & & $\begin{array}{l}\text { High grade: } \\
31.2 \% \\
\text { Low grade: } \\
100 \%\end{array}$ & $\begin{array}{l}\text { High grade: } \\
23.5 \% \\
\text { Low grade: } \\
90.0 \%\end{array}$ & $\begin{array}{l}\text { High grade: } \\
11.8 \% \\
\text { Low grade: } \\
80.0 \%\end{array}$ & \\
\hline & & & & $\begin{array}{l}\text { Surgery: } n=16 \\
\text { No surgery: } n=13\end{array}$ & & $\begin{array}{c}\text { Surgery: } \\
93.8 \% \\
\text { No surgery: } \\
53.8 \%\end{array}$ & $\begin{array}{c}\text { Surgery: } \\
93.8 \% \\
\text { No surgery: } \\
53.8 \%\end{array}$ & $\begin{array}{c}\text { Surgery: } \\
93.8 \% \\
\text { No surgery: } \\
53.8 \%\end{array}$ & \\
\hline Huo 2015 [23] & 26 & $\begin{array}{c}46.5 \text { years } \\
\text { (range, } 12- \\
79)\end{array}$ & $\begin{array}{c}\text { High grade: } \\
n=16 \text { Low } \\
\text { grade: } n=7\end{array}$ & $\begin{array}{c}\text { Surgery: } n=23 \\
\text { Radiotherapy: } n=4 \\
\text { Chemotherapy: } n=3\end{array}$ & $\begin{array}{c}\text { DFS } \\
\text { all patints:18 } \\
\text { month }\end{array}$ & & & & \\
\hline Wang 2015 [21] & 27 & $\begin{array}{l}\text { High grade: } \\
52.2 \text { years } \\
\text { Low grade: } \\
54.1 \text { years }\end{array}$ & $\begin{array}{c}\text { High grade: } \\
n=7 \\
\text { Low grade: } \\
n=25\end{array}$ & $\begin{array}{l}\text { Surgery: } n=18 \\
\text { No surgery: } n=9\end{array}$ & $\begin{array}{c}\text { 5-year DFS } \\
\text { High grade: } \\
57.1 \% \\
\text { Low grade: } \\
95.0 \%\end{array}$ & & & $\begin{array}{l}\text { High grade: } \\
42.9 \% \\
\text { Low grade: } \\
95.0 \%\end{array}$ & \\
\hline Jiang 2014 [26] & 34 & $\begin{array}{c}41 \text { years } \\
\text { (range, 16- } \\
78)\end{array}$ & $\begin{array}{c}\text { High grade: } \\
n=9 \\
\text { Low grade: } \\
n=25\end{array}$ & Surgery: $n=34$ & $\begin{array}{c}\text { 5-year PFS } \\
\text { all patints: } \\
81.6 \%\end{array}$ & & & $\begin{array}{c}\text { all patients: } \\
84.6 \%\end{array}$ & \\
\hline Zhu 2013 [24] & 69 & $\begin{array}{c}47.6 \text { years } \\
\text { (range, } 7-73 \text { ) }\end{array}$ & & $\begin{array}{c}\text { Surgery: } n=66 \\
\text { Chemotherapy: } n=3\end{array}$ & $\begin{array}{c}\text { 3-year DFS: } \\
94.7 \% \\
\text { 5-year DFS: } \\
87.3 \% \\
\text { 10-year DFS } \\
53.7 \%\end{array}$ & & $\begin{array}{c}\text { All patients: } \\
93.1 \%\end{array}$ & $\begin{array}{l}\text { All patients: } \\
89.5 \%\end{array}$ & \\
\hline Song 2013 [20] & 32 & $\begin{array}{c}28 \text { years } \\
\text { (range, } 7-73)\end{array}$ & $\begin{array}{c}\text { High grade: } \\
n=7 \\
\text { Low grade: } \\
n=25\end{array}$ & $\begin{array}{c}\text { Surgery: } n=28 \\
\text { Palliative resection: } \\
n=28\end{array}$ & & & & $\begin{array}{l}\text { High grade: } \\
28.6 \% \\
\text { Low grade: } \\
81.2 \%\end{array}$ & \\
\hline Xi 2012 [22] & 21 & & $\begin{array}{c}\text { High grade: } \\
n=4 \\
\text { Low grade: } \\
n=17\end{array}$ & & $\begin{array}{c}\text { PFS } \\
44.9 \text { month } \\
\text { (range, 5-77) }\end{array}$ & & & & $\begin{array}{c}\text { Overall survival } \\
46.6 \text { month (range, } 5-77 \text { ) }\end{array}$ \\
\hline
\end{tabular}


Citation: Nishie K, Yasuo M, Takahashi H, Ozawa Y, Tateishi K, et al. (2017) Bronchial Mucoepidermoid Carcinoma Successfully Treated with Radiation Therapy: A Case Report. Oncol Cancer Case Rep 3: 130.

Page 3 of 4

\begin{tabular}{|c|c|c|c|c|c|c|c|c|c|}
\hline Julian 2007 [19] & 20 & $\begin{array}{c}40 \text { years } \\
\text { (range, } 6-78)\end{array}$ & & Surgery: $n=19$ & $\begin{array}{c}\text { Surgery: } \\
94.0 \%\end{array}$ & $\begin{array}{l}\text { Surgery: } \\
94.0 \%\end{array}$ & $\begin{array}{l}\text { Surgery: } \\
88.0 \%\end{array}$ & & \\
\hline Yang 2004 [15] & 11 & $\begin{array}{c}58.9 \text { years } \\
\text { (range, 19- } \\
79)\end{array}$ & $\begin{array}{c}\text { High grade: } \\
\quad n=8 \\
\text { Low grade: } \\
n=3\end{array}$ & & & & $\begin{array}{c}\text { High grade: } \\
25.0 \% \\
\text { Low grade: } \\
100 \% \\
\end{array}$ & & \\
\hline \multirow[t]{2}{*}{ Vadasz 2000 [16] } & \multirow[t]{2}{*}{34} & \multirow{2}{*}{$\begin{array}{c}53 \text { years } \\
\text { (range, 34- } \\
70)\end{array}$} & $\begin{array}{c}\text { High grade: } \\
n=29 \\
\text { Low grade: } \\
n=5\end{array}$ & & & & $\begin{array}{c}\text { High grade: } \\
31.0 \%\end{array}$ & & \\
\hline & & & & Surgery: $n=34$ & & & $\begin{array}{l}\text { Surgery: } \\
80.0 \%\end{array}$ & & \\
\hline Suzuki 2000 [25] & 84 & $\begin{array}{l}\text { High grade: } \\
58.9 \text { years } \\
\text { Low grade: } \\
30.7 \text { years }\end{array}$ & $\begin{array}{c}\text { High grade: } \\
\text { n=24 } \\
\text { Low grade: } \\
n=60\end{array}$ & & & & & $\begin{array}{c}\text { Motality } \\
\text { Operative } \\
\text { Non operative }\end{array}$ & $\begin{array}{l}\text { High grade: } \\
50 \%(n=4) \\
\text { Low grade: } \\
0 \%(n=46) \\
\text { High grade: } \\
82 \%(n=17) \\
\text { Low grade: } \\
100 \%(n=3)\end{array}$ \\
\hline
\end{tabular}

DFS: Disease Free Survival, PFS: Progression Free Survival, OS: Overall Survival

Table 1: Summary of prognosis and treatment in pulmonary MEC.

tumor size was increasing from $4.8 \mathrm{~cm}$ to $6.5 \mathrm{~cm}$ and the trachea was compressed and deviated (Figure 1C). The patient was intubated for airway obstruction on day 20. RT was temporarily stopped because of severe respiratory status. Argon plasma coagulation was performed to remove the intratracheal stent where it had invaded the tumor. RT of 20 Gy given in 5 fractions was restarted on day 31. A physician stood by during RT in case of respirator bungle. In the course of treatment, the patient's respiratory status improved, and an additional course of RT with 20 Gy given in 5 fractions was applied. After $49 \mathrm{~Gy}$, the size of the tumor decreased to $3.1 \mathrm{~cm}$ (Figure 1D) and ventilatory support could be withdrawn. She recovered performance status 1 , chemotherapy (nab-Paclitaxel in combination with carboplatin) was started as first line. However, pneumonia in left upper lobe was occurred. After recovering, she treated with cisplatin and irinotecan as second line. Then she developed febrile neutropenia and sepsis due to pseudomonas aeruginosa. She died 8 months after diagnosis.

\section{Discussion}

We reported a case that tumor shrinkage was obtained by RT and it was possible to withdraw from a ventilator. This is the first case report in MEDLINE of an unresectable bronchial MEC treated with RT resulting in a partial response. Surgery is primarily choice for resectable tumors. However, no consensus has yet been reached in the treatment of advanced bronchial MEC. A few advanced bronchial MEC cases have been treated as NSCLC in clinical practice $[4,14]$. We summarized the papers reporting on the treatment and prognosis of pulmonary MEC (Table 1) [15-26]. Chin and colleagues examined 41 cases of surgical treatment and reported that 5-year survival rate of high-grade MEC was $53.2 \%$ and 5-year survival rate of low grade MEC was 66.7\% [17]. In addition, Hou et al. Reported 29 cases including nonsurgical treatment cases, high-grade MEC reported a 5-year survival rate of $11.8 \%$ and low grade MEC a 5-year survival rate of $80 \%$ [18]. In their cox regression analysis, histological grade and TNM stage and resectability were significantly associated with prognosis. Other reports described grade and operability as meaningful factors of prognosis [4,20]. In another report, age was also reported as a prognostic factor [22].

Few reports showed the effect of chemotherapy. Han and colleagues showed the effectiveness of gefitinib against pulmonary MEC. This was effective even in patients without EGFR mutation [14]. In addition, Sonobe et al. reported a case that carboplatin plus paclitaxel was used for unresectable pulmonary MEC patient with 25 months disease free survival [27].
The question remains as to whether or not RT is effective for bronchial MEC. Use of RT has not been widely discussed because the incidence of MEC is very low [28]. It was regarded to be ineffective for bronchial MEC because salivary gland tumors, which were pathologically identical to bronchial MEC, were considered resistant to RT [10-12]. However, the effectiveness of RT for salivary MEC has recently been reported. The 10 -year local control rates were $42 \%$ and the cause-specific survival rate was $44 \%$ for salivary tumor patients treated with RT alone. And almost $20 \%$ of that patients have been cured with $\mathrm{RT}$ alone [29]. Therefore, RT is now widely conducted in inoperable and postoperative salivary MEC and the results were reported as effective palliation and disease control $[30,31]$.

We assumed that the effectiveness of RT for bronchial MEC might be underestimated as for salivary MEC. The most significant differences between bronchial MEC and salivary MEC are symptoms such as bronchial obstruction and obstructive pneumonia, which can be critical. While local control is considered important in the treatment of advanced salivary MEC, size reduction is meaningful in patients with bronchial MEC suffering from the bronchial stenosis. In the present case, the tumor decreased in size after RT allowing to be weaned from ventilation and it might be prolonged the survival and enabled to recover. Perhaps best supportive care would have been chosen if RT was thought to be ineffective for bronchial MEC. Therefore, re-evaluation of the effectiveness of RT for bronchial MEC is needed. Kanemoto et al. described a case treated with proton beam therapy (PBT) for an inoperable recurrence of bronchial high-grade MEC. After the third course of PBT, a disease-free status was maintained for 1 year [28]. PBT uses the same mechanism as RT to kill tumor cells, and this case also supports the effectiveness of RT for unresectable bronchial MEC.

\section{Conclusion}

We reported a case of tracheal stenosis induced by bronchial MEC that was successfully treated with RT. This case suggests that RT is a treatment option for unresectable bronchial MEC.

\section{Conflict of Interest Statement}

We The authors have no conflicts of interest to report.

\section{Acknowledgement}

The authors would like to thank Dr. Yuden Droma for her valuable advice and for kindly checking the English language usage in our manuscript. 
Citation: Nishie K, Yasuo M, Takahashi H, Ozawa Y, Tateishi K, et al. (2017) Bronchial Mucoepidermoid Carcinoma Successfully Treated with Radiation Therapy: A Case Report. Oncol Cancer Case Rep 3: 130.

\section{References}

1. Colby TKM, Travis W (1995) Tumors of salvary gland type. In: Tumors of the lower Respiratory Tract. Atlas of Tumor Pathology. Washington DC: Armed Forces Institute of Pathology p. 65-89.

2. Heitmiller RF, Mathisen DJ, Ferry JA, Mark EJ, Grillo HC (1989) Mucoepidermoid lung tumors. Ann Thorac Sur 47: 394-399.

3. Smetana HF, Iverson L, Swan LL (1952) Bronchogenic carcinoma. An analysis of 100 autopsy cases. Mil Surg 111: 335-351.

4. Yousem SA, Hochholzer L (1987) Mucoepidermoid tumors of the lung. Cancer 60:1346-1352.

5. Rankin JK, Jakobiec FA, Zakka FR, Foster CS (2012) An improved approach to diagnosing and treating conjunctival mucoepidermoid carcinoma. Survey of Ophthalmology 57: 337-346.

6. Barnes L, Eveson JW (2005) World Health Organization: Classification of tumours, Pathology and Genetics, Head and Neck Tumours. IARC Press: Lyon p. 219-220.

7. Liu X, Adams AL (2007) Mucoepidermoid carcinoma of the bronchus: a review. Arch Pathol Lab Med 131: 1400-1404.

8. Santambrogio L, Cioffi U, De Simone M, Rosso L, Ferrero S, et al. (2002). Video-assisted sleeve lobectomy for mucoepidermoid carcinoma of the left lower lobar bronchus: A case report. Chest 121: 635-636.

9. Li CH, Huang SF, Li HY (2004) Bronchoscopic Nd-YAG laser surgery for tracheobronchial mucoepidermoid carcinoma-A report of two cases. International journal of clinical practice 58: 979-982.

10. Ozawa H, Tomita T, Sakamoto K, Tagawa T, Fujii R, et al. (2008) Mucoepidermoid carcinoma of the head and neck: clinical analysis of 43 patients. Jpn J Clin Oncol 38: 414-418.

11. Giusti RJ, Flores RM (2004) Mucoepidermoid carcinoma of the bronchus presenting with a negative chest $\mathrm{X}$-ray and normal pulmonary function in two teenagers: two case reports and review of the literature. Pediatr Pulmonol 37: $81-84$

12. Moon M, Kohno T, Hamamoto A, Yoshiya TRU (2007) Two cases of high-grade malignancy bronchial mucoepidermoid carcinoma in young adult. The Journal of the Japanese Association for Chest Surgery 21: 718-723.

13. Goode RK, Auclair PL, Ellis GL (1998) Mucoepidermoid carcinoma of the major salivary glands: clinical and histopathologic analysis of 234 cases with evaluation of grading criteria. Cancer 82: 1217-1224.

14. Han SW, Kim HP, Jeon YK, Oh DY, Lee SH, et al. (2008) Mucoepidermoid carcinoma of lung: potential target of EGFR-directed treatment. Lung Cancer 61: 30-34.

15. Yang CS, Kuo KT, Chou TY, Lin CM, Hsu WH, et al. (2004) Mucoepidermoid tumors of the lung: Analysis of 11 cases. J Chin Med Assoc 67: 565-570.
16. Vadasz P, Egervary M (2000) Mucoepidermoid bronchial tumors: a review of 34 operated cases. Eur J Cardiothorac Surg 17: 566-569.

17. Hsieh CC, Sun YH, Lin SW, Yeh YC, Chan ML (2017) Surgical outcomes of pulmonary mucoepidermoid carcinoma: A review of 41 cases. PLoS One 12: e0176918.

18. Hou J, Wang H, Zhang G, Huang Y, Ma Z (2017) [Mucoepidermoid Carcinoma of the Lung: Report of 29 Cases. Zhongguo Fei Ai Za Zhi 20: 168-174.

19. Molina JR, Aubry MC, Lewis JE, Wampfler JA, Williams BA, et al. (2007) Primary salivary gland-type lung cancer: spectrum of clinical presentation, histopathologic and prognostic factors. Cancer 110: 2253-2259.

20. Song Z, Liu Z, Wang J, Zhu H, Zhang Y (2013) Primary tracheobronchia mucoepidermoid carcinoma--a retrospective study of 32 patients. World J Surg Oncol 11: 62.

21. Wang M, Ouyang S, Sun P, Li D, Huang G (2015). Pulmonary mucoepidermoid carcinoma in Chinese population: a clinicopathological and radiological analysis. Int J Clin Exp Pathol 8: 3001-3007.

22. Xi JJ, Jiang W, Lu SH, Zhang CY, Fan H, et al. (2012) Primary pulmonary mucoepidermoid carcinoma: an analysis of 21 cases. World J Surg Oncol 10: 232.

23. Huo Z, Wu H, Li J, Li S, Wu S, et al. (2015) Primary Pulmonary Mucoepidermoid Carcinoma: Histopathological and Moleculargenetic Studies of 26 Cases. PLoS One 10: e0143169.

24. Zhu F, Liu Z, Hou Y, He D, Ge X, et al. (2013) Primary salivary gland-type lung cancer: clinicopathological analysis of 88 cases from China. J Thorac Oncol 8: 1578-1584.

25. Suzuki K, Mori Y, Nakata H, Ohnishi T, Abe S (2000) A case of mucoepidermoid carcinoma treated by sleeve resection of truncus intermedius -A clinical review of 104 reported cases in Japanese. Haigan 40: 121-127.

26. Jiang L, Li P, Xiao Z, Qiu H, Zhang X, et al. (2014) Prognostic factors of primary pulmonary mucoepidermoid carcinoma: An clinical and pathological analysis of 34 cases. Int J Clin Exp Pathol 7: 6792-6799.

27. Sonobe S, Inoue K, Tachibana S, Shiojiri M, Maeda T, et al. (2014) A case of pulmonary mucoepidermoid carcinoma responding to carboplatin and paclitaxel. Jpn J Clin Oncol 44: 493-496.

28. Kanemoto A, Oshiro Y, Sugahara S, Kamagata S, Hirobe S, et al. (2012) Proton beam therapy for inoperable recurrence of bronchial high-grade mucoepidermoid carcinoma. Jpn J Clin Oncol 42: 552-555.

29. Mendenhall WM, Morris CG, Amdur RJ, Werning JW, Villaret DB (2005) Radiotherapy alone or combined with surgery for salivary gland carcinoma. Cancer 103: 2544-2550.

30. Iqbal $H$, Bhatti AB, Hussain $R$, Jamshed A (2014) Ten-year experience with surgery and radiation in the management of malignant major salivary gland tumors. Asian Pac J Cancer Prev 15: 2195-2199.

31. Pfister DG, Spencer S (2015) NCCN Clinical Practice Guidelines in Oncology Head and Neck Cancers version 1. 